\title{
AVALIAÇÃO DA DISTRIBUIÇÃO DO PRONAF ENTRE AS REGIÕES GEOGRÁFICAS DO BRASIL
}

\section{EVALUATION OF THE PRONAF DISTRIBUTION AMONG THE GEOGRAPHICAL REGIONS OF BRAZIL}

\section{EVALUACIÓN DE LA DISTRIBUCIÓN DE PRONAF ENTRE LAS REGIONES GEOGRÁFICAS DE BRASIL}

\author{
José Giacomo Baccarin ${ }^{1}$ \\ https://orcid.org/0000-0002-8120-3621 \\ Jonatan Alexandre de Oliveira ${ }^{2}$ \\ https://orcid.org/0000-0002-2326-5912
}

Submissão: 13/05/2020 / Aceito: 20/07/2020.

\begin{abstract}
Resumo
Em 1996, foi criado o Programa Nacional de Fortalecimento da Agricultura Familiar (Pronaf) propiciando crédito rural a agricultores familiares do Brasil, com taxas de juros subsidiadas. Existem agricultores familiares modernizados, integrados a mercados e com maior nível de renda, bem como os de subsistência, sem técnicas modernas e em condição de pobreza. O objetivo é analisar a distribuição do Pronaf entre os diferentes tipos de agricultores familiares, de acordo com a renda obtida, para o período 1999 a 2019. Isto não será feito de forma direta, mas através do estudo da aplicação do Pronaf em diferentes regiões geográficas brasileiras, em especial as Nordeste e Sul, em que se concentram a grande maioria dos agricultores familiares, muito empobrecidos na primeira e mais modernizados na segunda. Usam-se dados, principalmente, do Instituto Brasileiro de Geografia e Estatística e Banco Central do Brasil. De 1999 a 2019, ainda que não de forma linear, houve forte expansão dos créditos do Pronaf no Brasil e em suas regiões. Os agricultores do Nordeste ampliaram muito a participação no número dos contratos e pouco nos recursos; os do Sul perderam importância nos recursos e mais nos contratos; os do Sudeste e Norte elevaram a participação nos dois quesitos e; os do Centro-Oeste mantiveram participação pouco expressiva no Programa. Entre 2003 e 2006, as intenções distributivistas dos recursos em favor de agricultores mais pobres mostrou forte efetividade, com aumento de participação dos agricultores do Nordeste, associado a mudanças institucionais, como a criação do Pronaf Semiárido. Contudo, a partir de 2007, outras modificações, como elevação da renda máxima para enquadramento e limites de crédito de custeio e investimento, beneficiaram agricultores familiares mais ricos, de forma que os recursos voltassem a se concentrar. Em relação a 2001, constatava-se melhor distribuição, em 2019, dos recursos do Pronaf entre as regiões brasileiras, ainda que a redistribuição mais drástica, de 2003 e 2006, não se mantivesse.
\end{abstract}

Palavras-chave: Pronaf, crédito rural, agricultura familiar.

\footnotetext{
${ }^{1}$ Professor Livre Docente: Faculdade de Ciências Agrárias e Veterinárias, UNESP, campus de Jaboticabal (SP). Email: jose.baccarin@unesp.br .

${ }^{2}$ Doutorado em Geografia: Instituto de Geociências e Ciências Exatas, UNESP, campus Rio Claro (SP). Bolsista de Desenvolvimento Tecnológico Industrial - A (CNPq). E-mail: jonatan.oliveira@unesp.br .
} 


\begin{abstract}
In 1996, the National Program for Strengthening Family Farming (Programa Nacional de Fortalecimento da Agricultura Familiar, PRONAF) was created for providing rural credit with subsidized interest rates to family farmers in Brazil. Family farmers are divided into two groups, those integrated into markets with higher income levels and subsistence farmers, poorer and lacking modern techniques. The objective is to evaluate PRONAF resources' distribution among the different groups of family farmers, between 1999 and 2019. This research evaluates two parameters, the number of contracts and financial resources allocated, and distribution among different geographical regions, especially the Northeast and South regions. These two regions concentrate most Brazilian family farmers, with very impoverished farmers in the Northeast region and more modernized and, generally, better off in the South. The data were provided by the Brazilian Institute of Geography and Statistics and the Central Bank of Brazil. From 1999 to 2019, although not linear, the PRONAF credit expanded strongly in Brazil and its regions. The number of contracts increased greatly while financial resources increased little in the Northeastern; allocated financial resources decreased while the number of contracts decreased even more in the South; both parameters increased in the Southeast and North regions; and, the Midwest small participation in the program was maintained. Between 2003 and 2006, associated with institutional changes, e.g. the creation of PRONAF Semiárido, the program resources were distributed among poorer farmers very effectively as indicated by the increasing participation of farmers in the Northeast. However, in 2007, the income threshold and loan limits for applying to cost and investment loans were raised, benefiting richer family farmers so that the resources became more concentrated again. Furthermore, although the more drastic redistribution of resources observed between 2003 and 2006 was not maintained, the PRONAF resources were better distributed among the different Brazilian regions in 2019 compared to 2001.
\end{abstract}

Keywords: Pronaf, rural credit, farm agriculture.

\title{
Resumen
}

En 1996, se creó el Programa Nacional para el Fortalecimiento de la Agricultura Familiar (Pronaf), que otorga crédito rural a los agricultores familiares en Brasil, con tasas de interés subsidiadas. Hay agricultores familiares modernizados, integrados en los mercados y con un mayor nivel de ingresos, así como agricultores de subsistencia, sin técnicas modernas y en condiciones de pobreza. El objetivo es analizar la distribución de Pronaf entre los diferentes tipos de agricultores familiares, de acuerdo con los ingresos obtenidos, para el período 1999 a 2019. Esto no se hará directamente, sino a través del estudio de la aplicación de Pronaf en diferentes regiones geográficas. Brasileñas, especialmente el noreste y el sur, donde se concentra la gran mayoría de los agricultores familiares, muy empobrecidos en el primero y más modernizados en el segundo. Los datos se utilizan principalmente del Instituto Brasileño de Geografía y Estadística y del Banco Central de Brasil. De 1999 a 2019, aunque no de manera lineal, hubo una fuerte expansión de los créditos de Pronaf en Brasil y sus regiones. Los agricultores del noreste han aumentado considerablemente la participación en la cantidad de contratos y pocos recursos; los del sur perdieron importancia en recursos y más en contratos; los del sudeste y norte aumentaron la participación en ambos artículos y; los del medio oeste mantuvieron poca participación en el programa. Entre 2003 y 2006, las intenciones distributivas de los recursos en favor de los agricultores más pobres mostraron una gran efectividad, con un aumento en la participación de los agricultores en el noreste, asociado con cambios institucionales, como la creación de Pronaf Semiárido. Sin embargo, a partir de 2007, 
otros cambios, como el aumento del ingreso máximo para el marco y los límites de crédito para costos e inversiones, beneficiaron a los agricultores familiares más ricos, por lo que los recursos podrían concentrarse nuevamente. En relación con 2001, hubo una mejor distribución, en 2019, de los recursos de Pronaf entre las regiones brasileñas, aunque la redistribución más drástica de 2003 y 2006 no continuó.

Palabras Clave: Pronaf, crédito rural, agricultura familiar.

\section{INTRODUÇÃO}

O sistema de crédito ganhou uma sofisticação e alcance muito grandes na sociedade contemporânea. Sobre o ponto de visto produtivo, ele potencializa ações das empresas no curto prazo, garantindo-lhe o chamado capital de giro ou crédito de custeio. Também contribui para adoção de inovações tecnológicas e aumento da capacidade produtiva e produtividade, via crédito de investimento, de longo prazo. Abstraindo os seus efeitos sobre a instabilidade econômica, associados à especulação financeira, pode-se admitir que o crédito seja um dinamizador da economia.

Através de diferentes instrumentos são estabelecidas taxas de juros diversas para captação e concessão de recursos monetários pelos agentes financeiros, entre eles os bancos, do sistema de crédito. A riqueza acumulada dos clientes, o tempo de retorno dos investimentos e os riscos dos negócios influenciam no valor das taxas e volume de empréstimo. Comumente, o mercado privado favorece grandes tomadores de crédito, de ramos com perspectivas de melhor e mais rápidos ganhos econômicos, o que tende a reforçar a concentração de renda (SAYAD, 1984).

É comum que os governos intervenham no sistema privado, entre outras medidas, através da criação de programas de crédito subsidiado (com menores taxas de juros) a empresas de menor porte e de setores com maiores riscos e menor rentabilidade, como pode ser considerada, mesmo que com alguma polêmica, a agricultura. Neste caso, além de se procurar garantir a oferta de alimentos, tal atitude encontra sua justificativa em características da produção e mercado de produtos agrícolas, como a sazonalidade produtiva, a instabilidade de preços e os riscos climáticos e sanitários envolvidos, com influência negativa na renda setorial (BUAINAIN \& SOUZA FILHO, 2009; DELGADO, 2001).

No Brasil destacam-se duas datas em termos de mudanças institucionais mais abrangentes na concessão de crédito rural. A primeira, em 1965, quanto se criou o Sistema Nacional de Crédito Rural (SNCR) e se determinou que todos os bancos emprestassem um porcentual mínimo de seus 
depósitos à vista (inicialmente, 10\%), chamado de exigibilidade, em operações de crédito rural, com taxas de juros bem abaixo das praticadas em outras operações de empréstimo e financiamento.

Outra data é 1996, com a instituição do Programa Nacional de Fortalecimento da Agricultura Familiar (Pronaf), destinado ao financiamento de projetos de custeio e investimento exclusivos de agricultores familiares, com taxas de juros ainda mais baixas que as do SNCR. Diferentemente deste, contudo, a oferta do Pronaf se restringe a três bancos públicos federais (Banco do Brasil-BB, Banco do Nordeste do Brasil-BNB e Banco da Amazônia Sociedade Anônima-BASA), um pequeno banco regional (Banco Regional de Brasília-BRB) e cooperativas de crédito rural (BACCARIN, 2011).

Em termos de aplicação e distribuição de crédito, pode-se dizer que os bancos privados vêm cumprindo a exigibilidade do SNCR, ainda que priorizem a concessão de recursos para grandes agricultores, em menor número de contratos, diminuindo custos operacionais e administrativos. Além disto, grandes agricultores garantem maior reciprocidade aos bancos, em termos de aquisição de serviços, como seguros e previdência privada, ou de aplicações financeiras a curto e longo prazo. Em 2012, os bancos privados no Brasil concederam 33\% do volume financeiro de crédito rural, mas tiveram participação de apenas $8 \%$ no número de contratos (BCB, 2013).

Neste mesmo ano, os bancos oficiais federais tiveram participação de $54 \%$ no volume financeiro e 78\% no número de contratos do crédito rural (BCB, 2013). Antes de expressar uma tradição na ação destes bancos, isto demonstra sua obrigatoriedade de executarem operações do Pronaf e revela que, efetivamente, conseguiu-se um mecanismo institucional de favorecimento, mesmo que insuficiente, aos agricultores familiares.

Segundo a lei 11.326/2006, agricultor familiar é todo aquele cujo estabelecimento agropecuário não ultrapassa quatro módulos fiscais ${ }^{3}$. Além disto, o agricultor familiar deve usar, de forma predominante, a força de trabalho da própria família, gerir diretamente o estabelecimento e depender, majoritariamente, para sua sobrevivência da renda nele obtida (BRASIL, 2015).

Apesar destas características comuns, seria um equívoco tomar o agrupamento agricultores familiares como homogêneo. Guanzirolli et al. (2009) estimam que, em 2006, os agricultores familiares com renda superior a três vezes o valor anualizado da diária regional (os mais ricos ou

\footnotetext{
${ }^{3} \mathrm{O}$ tamanho do módulo fiscal é definido pelo Instituto Nacional de Colonização e Reforma Agrária (INCRA) como a menor unidade agrícola que, nas condições médias de cada município brasileiro, permitiria a reprodução social de seus detentores.
} 
menos pobres) representavam $9 \%$ do total de agricultores familiares. Os que contavam com renda entre metade e três vezes o valor anualizado da diária regional eram 33\% e os que percebiam menos que a metade daquele valor eram $58 \%$ do total. Enquanto o primeiro grupo era responsável por $68 \%$ do valor bruto da produção da agricultura familiar, o segundo tinha participação de $21 \%$ e o terceiro, de apenas $11 \%$.

Existem agricultores familiares que usam tecnologias modernas, com atividades econômicas integradas ao mercado, embora sujeitos a condições menos favoráveis em relação aos preços pagos e recebidos pelos grandes agricultores. Existem também os que praticam agricultura de subsistência, vivem em condições de pobreza, sendo que muitas vezes obtêm parcela de seu rendimento através do assalariamento temporário, fora de seus estabelecimentos agropecuários.

Uma indagação que pode ser feita é se o Pronaf consegue atender de forma equânime agricultores familiares em diferentes situações sociais. Em princípio, assume-se a hipótese de que, após o Pronaf, mesmo que o conjunto dos agricultores familiares tenha alcançado uma participação no volume de crédito maior que anteriormente, nem todas as suas frações foram suficientemente atendidas.

O objetivo geral do presente artigo é avaliar a distribuição do Pronaf entre diferentes tipos de agricultores familiares, classificados de acordo com a renda obtida, de 1999 a 2019. Isto não será feito de forma direta, mas através da comparação da aplicação do Pronaf em diferentes regiões geográficas brasileiras, em especial as Nordeste e Sul, em que se concentram a grande maioria dos agricultores familiares, muito empobrecidos na primeira e mais modernizados na segunda.

Especificamente, pretende-se traçar um paralelo entre a evolução do volume financeiro do Pronaf e do total de crédito rural no Brasil e comparar a evolução de seus recursos e número de contratos nas regiões geográficas, respectivamente, com a renda e o número dos agricultores familiares aí existentes.

Além da introdução, o trabalho está dividido em quatro seções. Na segunda revisa-se a literatura, destacando interpretações diversas sobre o alcance social e econômico do Pronaf, bem como mapeando suas mudanças institucionais, a partir da safra 1999/2000. A terceira trata das fontes de informações e dados e de como eles foram trabalhados. A quarta seção apresenta os resultados do trabalho e encerra-se com algumas considerações finais. 


\section{EFETIVIDADE ECONÔMICA E SOCIAL DO PRONAF}

Como já afirmado, em 1965, o Governo Brasileiro instituiu o SNCR, impondo aos bancos instalados no País (públicos e privados) a obrigação de aplicar no mínimo $10 \%$ dos recursos captados através de depósitos à vista em operações de crédito rural, cujas taxas de juros eram fixadas publicamente. Este porcentual variou ao longo do tempo, chegando a ultrapassar $40 \%$ no final da década de 1970 e, em 2019, era de 30\% (BACCARIN, 2011, BCB, 2020).

A pesquisa agropecuária e o crédito rural são consideradas as principais políticas que, a partir dos anos 1970, promoveram importantes mudanças tecnológicas e aumentaram a produção primária do Brasil, que se transformou em um dos maiores exportadores mundiais agrícolas. Contudo, estes efeitos produtivos e tecnológicos tenderam a beneficiar mais amplamente médios e grandes agricultores, excluindo pequenos agricultores e contribuindo para aceleração do êxodo rural (SAYAD, 1984).

Nos anos 1990, com o Brasil formalmente redemocratizado, movimentos sindicais ligados à Confederação Nacional dos Trabalhadores da Agricultura (CONTAG) e ao Departamento Nacional de Trabalhadores Rurais da Central Única dos Trabalhadores (DNTR/CUT), entre outras entidades, conseguiram expressar mais efetivamente suas reivindicações em favor da formulação e implantação de políticas de desenvolvimento rural e acesso aos serviços oferecidos pelo sistema nacional financeiro (MATTEI, 2007). Ao mesmo tempo, estudos, como o realizado em parceria pela regional brasileira da Organização das Nações Unidas para Agricultura e Alimentação (FAO) e INCRA, ressaltavam o papel social da agricultura familiar, mostravam sua diferenciação interna e estabeleciam uma série de diretrizes e formulações que vieram a contribuir para o novo cenário do desenvolvimento das políticas públicas para a agricultura (AZEVEDO e PESSÔA, 2011).

Estes fatos, mais a crise de renda que se abateu sobre toda agricultura brasileira e o aumento do número de mortes de agricultores sem-terra em conflitos agrários, em 1995 e 1996, levaram o Governo Federal a promover inovações institucionais em favor da pequena agricultura (BACCARIN, 2011). Ainda em 1996, foi criado um ministério específico para reforma agrária e agricultura familiar, que se chamaria, mais adiante, Ministério de Desenvolvimento Agrário (MDA). Já o Decreto Presidencial 1.946, de 28/06/1996, instituiu o Pronaf para financiar projetos individuais ou coletivos para custeio e investimento da agricultura familiar, com as menores taxas 
de juros do mercado de crédito rural (BRASIL, 1996). Embora com alcance reduzido, estas inovações institucionais confrontaram a orientação geral da política agrícola da década de 1990, de desregulamentação e menor intervenção pública nos mercados.

O Pronaf veio cercado de expectativas muito positivas por parte de vários cientistas sociais. Sachs (2001, pag. 77) entendia que o Programa rompia “...com a prática do apoio exclusivo à agricultura patronal e ao agribusiness, considerados como único caminho viável de modernização para a agricultura brasileira". Foram citados também efeitos favoráveis ao desenvolvimento regional e aumento da oferta de alimentos ${ }^{4}$, que poderiam resultar em maior estabilidade de seus preços e preservação do salário real (CONTI \& ROITMAN, 2011).

O subsídio nos juros do Pronaf se justificava pelo fato dos agricultores familiares, com baixa produtividade e descapitalizados, não estarem em condições de tomar empréstimos em condições comerciais para realizar os investimentos em modernização e elevação da produtividade. Pelo menos na etapa inicial do processo de acumulação, os seus rendimentos não seriam compatíveis nem suficientes para reembolsar empréstimos tomados a juros de mercado (GUANZIROLLI, 2007).

Outra característica que se pode destacar no Programa é a consideração de diferentes condições sociais e produtivas dos agricultores familiares, com a formulação de linhas específicas para a concessão de crédito. Existem modalidades destinadas aos jovens, às mulheres, aos assentados de reforma agrária, que praticam extrativismo, que se dedicam à produção agroecológica etc. Além disto, desde 1999, o Pronaf tem considerado a existência de diferentes grupos de agricultores familiares, de acordo com o nível da Renda Bruta Familiar (RBF) obtida em determinado ano (MATTEI, 2007; NUNES, 2007; SCHNEIDER et al., 2004). Para Bianchini (2015), isto permitiu criar diferenciação dos agricultores em relação a limites, taxa de juros e volume de crédito.

Esta construção institucional, em princípio, revela a intenção de democratização (em termos sociais) da concessão de crédito, contemplando também aqueles agricultores familiares mais empobrecidos, não apenas os mais tecnificados e com renda mais alta.

\footnotetext{
${ }^{4}$ Estima-se que, em 2006, $87 \%$ da produção brasileira de mandioca, $70 \%$ de feijão, $46 \%$ do milho, $38 \%$ do café, $33 \%$ do arroz e 58\% do leite originavam-se da agricultura familiar, que, ao mesmo tempo, possuía 59\% do plantel de suínos, $51 \%$ de aves e $30 \%$ dos bovinos (IBGE, 2009).
}

DOI: http://dx.doi.org/10.22295/grifos.v30i51.5477 | Edição Vol. 30, Núm. 51, 2021. 
Isso se choca com a racionalidade econômica do mercado financeiro, que tende a direcionar mais crédito justamente para os segmentos sociais mais enriquecidos. Como demonstra a experiência já comentada do crédito rural convencional no Brasil, as agências bancárias tendem a cumprir sua obrigação legal na aplicação dos recursos creditícios, concentrando-os em projetos de grandes agricultores, obtendo maior reciprocidade e diminuindo custos administrativos.

Não se elimina a hipótese de que algo semelhante, guardada as devidas proporções, possa ter acontecido com o Pronaf, com os agentes bancários encarregados de sua execução beneficiando mais os agricultores familiares mais capitalizados. Para Souza et al. (2013), estes agricultores garantem aos bancos garantias, contratos e juros maiores. É importante destacar que as modalidades para agricultores mais pobres contam com menores taxas de juros que em outras linhas do Pronaf, além de, comumente, preverem bônus de adimplência.

Ao mesmo tempo, pode-se levantar o argumento de que o Pronaf tem seus recursos concentrados nos agricultores familiares mais ricos, pois estes apresentam maior participação no valor da produção deste segmento social. Nesta suposição, haveria uma racionalidade econômica na distribuição dos recursos creditícios.

Souza et al. (2015), a partir de dados do Censo Agropecuário 2006, informam que os 50\% menores estabelecimentos agropecuários, em termos de valor da produção, recebiam porcentual de crédito proporcionalmente menor, de 35\%. Afirmam também que o Pronaf exercia papel ativo na redistribuição do crédito oficial entre os estabelecimentos agropecuários no Brasil, ou seja, sem este Programa a concentração do crédito seria ainda maior.

Em termos da distribuição dos recursos do Pronaf entre as regiões, vários autores têm questionado sua capacidade de atender agricultores familiares do Nordeste, cuja renda média é bem menor do que a de outras regiões (vide Tabela 2 mais adiante), e se concentrar muito no Sul. Esta desigualdade na distribuição regional de recursos já era apontada no início da operacionalização do Pronaf por Abramovay e Veiga (1999).

Em estudo realizado sobre a participação dos grupos A e A/C (menos capitalizados) na contratação de recursos do Pronaf, Mattei (2014, p. 67) chama atenção para a baixíssima participação desses grupos, a notável queda na participação dos recursos, ao longo dos anos, e para o problema "tantas vezes já debatido" da concentração de recursos na Região Sul. Apesar da remuneração dos custos administrativos das operações contratuais, da equalização da taxa de juros

\section{DOI: http://dx.doi.org/10.22295/grifos.v30i51.5477 | Edição Vol. 30, Núm. 51, 2021.} Este é um artigo publicado em acesso aberto (Open Access) sob a licença Creative Commons Attribution, que
permite uso, distribuição e reprodução em qualquer meio, sem restrições desde que o trabalho original seja corretamente citado. 
e do pagamento do spread bancário, feitos pelo Governo Federal ao sistema bancário, estes ainda continuam trabalhando com seus "clientes preferenciais, o que acaba dificultando e limitando o acesso às diferentes modalidades de crédito por parte de todos os segmentos de agricultores familiares". Argumentos parecidos são expressos por Silva e Filho (2009) e Abramovay e Piketty (2005).

Para Aquino e Schneider (2015, p. 76), a capacidade de redistribuição dos recursos do Pronaf em favor de agricultores menos capitalizados é baixa em decorrência de “... limites estruturais que se relacionam, seja ao formato institucional desta política, seja ao comportamento dos agentes operadores de que ela depende".

\section{MUDANÇAS INSTITUCIONAIS NO PRONAF}

Quanto ao formato institucional, os autores Aquino e Schneider (2015), informam que as mudanças que foram ocorrendo ao longo do tempo, como a ampliação do limite financeiro de enquadramento ao Programa, sancionaram o direcionamento de recursos para os agricultores familiares com maior renda. Em termos dos agentes operadores do Pronaf, além das questões anteriormente citadas, pode-se levantar a suposição de que os mesmos tenham atuado em desfavor de contratos de menor valor, em decorrência de uma provável ocorrência de níveis de inadimplência mais altos nas faixas de pronafianos mais empobrecidos. Até onde se conseguiu perceber, este ponto não teve ainda confirmação empírica na literatura.

O Quadro 1 resume e esquematiza algumas das mudanças institucionais do Pronaf no período de análise. Aí não estão registradas as condições de crédito para agricultores do Grupo A, que são os assentados de reforma agrária ou beneficiados por crédito fundiário oficial, a cargo do INCRA. Os do Grupo B podem também acessar o chamado microcrédito rural, que permite pequenos investimentos, inclusive em atividades não agrícolas. Estão previstos bônus de adimplência em operações de crédito destes dois grupos, A e B. 
Quadro 1 - Grupo de agricultores para enquadramento e condições de financiamento de custeio e investimento do Pronaf, mil reais e porcentual anual, 1999 a 2020.

\begin{tabular}{ccccc|cccc}
\hline \multirow{2}{*}{ Safra } & \multicolumn{3}{c}{ Limite de Renda Anual } & \multicolumn{2}{c}{ Custeio } & \multicolumn{2}{c}{ Investimento } \\
\cline { 2 - 9 } & B & C & D & E & Limite & Juros & Limite & Juros \\
\hline $1999 / 00$ & 1,5 & 8 & 27,5 & - & - & - & - & - \\
\hline $2003 / 04$ & 2 & 14 & 40 & - & 6 & 2 a 4 & 27 & 1 a 3 \\
\hline $2004 / 05$ & 2 & 16 & 45 & 60 & 28 & 2 a 4 & 54 & 1 a 7,25 \\
\hline $2008 / 09$ & 5 & \multicolumn{3}{c}{$110($ Grupo V $)$} & 30 & $1,5-5,5$ & 100 & 0,5 a 5 \\
\hline $2011 / 12$ & 6 & $110(220$ alguns produtos*) & 50 & $1,5-4,5$ & 130 & 0,5 a 4 \\
\hline $2012 / 13$ & 10 & $160(220$ alguns produtos* $)$ & 80 & 1,5 a 4 & 130 & 0,5 a 2 \\
\hline $2013 / 14$ & 20 & 360 & 100 & $1,5-3,5$ & $150-300$ & 0,5 a 2 \\
\hline $2015 / 16$ & 20 & 360 & 100 & $2,5-5,5$ & $150-300$ & 5,5 \\
\hline $2017 / 18$ & 23 & 360 & 250 & $2,5-4,5$ & 330 & 4,6 \\
\hline $2019 / 20$ & 23 & 415 & 250 & $3,0-4,6$ & 330 & $3,0-4,6$ \\
\hline
\end{tabular}

Fonte: BRASIL (2020). Valores não deflacionados. *Arroz, feijão, milho, soja, trigo e bovinocultura de corte.

Na safra 1999/2000, os agricultores familiares passaram a ser distribuídos em três grupos (B, C e D), com juros diferenciados, de acordo com a renda anual obtida. Grisa e Wesz Junior (2010) informam que, de 2003 em diante, foram criadas linhas especiais de crédito, como o Pronaf Semiárido, Jovem, Mulher, Agroecologia, Floresta, Cota-Parte e Agroindústria, procurando-se alcançar maior número de agricultores familiares, em maior diversidade e distribuídos por todo o território nacional, diminuindo a concentração de recursos na Região Sul. Neste sentido, destaque o Pronaf Semiárido e o Pronaf Floresta, para agricultores do Nordeste e Norte, respectivamente.

Ao mesmo tempo, contudo, os limites de enquadramento nos grupos e de crédito foram se ampliando, possibilitando a entrada de agricultores familiares com maiores rendas no Programa. Na safra 2004/05, criou-se novo grupo de agricultores familiares, o E, com maior renda anual para enquadramento, ao mesmo tempo que mais que se quadruplicava o limite de crédito de custeio e dobrava o limite de crédito de investimento.

Em 2008/09, os grupos C, D e E foram unificados no grupo V (renda variável), a renda anual máxima para enquadramento passou a ser de $\mathrm{R} \$ 110$ e o limite de crédito de investimento quase que dobrou. Este tipo de crédito passou a se chamar Pronaf Mais Alimentos, com objetivo de destinar recursos para investimentos em infraestrutura do estabelecimento agropecuário e acelerar sua modernização através da compra de máquinas e implementos, fato condizente com interesses da indústria nacional de tratores e, provavelmente, com demandas originárias de agricultores familiares da Região Sul. 
A tendência de aumento dos limites de renda para enquadramento e dos valores financiados continuaram nas safras seguintes. Na de 2013/14, o agricultor poderia declarar uma renda anual de até R \$ 360 mil para se habilitar a receber créditos do Pronaf ${ }^{5}$, contar com crédito de custeio de até R\$ 100 mil/ano e de investimento de até R\$ 150 mil/ano (R\$ 300 mil/ano na avicultura, suinocultura e fruticultura). Outro destaque é o aumento do limite para custeio na safra 2017/18, que passou a ser de $\mathrm{R} \$ 250 \mathrm{mil}$.

Ou seja, evidenciou-se a opção de ampliar o público do Programa, com a incorporação de agricultores com maior renda bruta, localizados, especialmente, em regiões com agricultura modernizada. Este direcionamento mostrou-se contrário às ações, destacadas no início, que procuraram incorporar agricultores em diferentes situações sociais, mais pobres e com forte concentração no Nordeste ${ }^{6}$.

Portanto, houve mudanças intitucionais associadas tanto à redistribuição, no começo deste século, quanto à reconcentração do crédito, posteriormente. Isto, muito provavelmente, esteve relacionado a pressões exercidas pelos operadores bancários do Programa e de agricultores mais capitalizados. Por exemplo, o Programa Mais Alimentos, permitiu acelerar a tecnificação de agricultores familiares, em especial, os com maiores renda, além de contribuir para a elevação da venda de tratores e outras máquinas agrícolas.

\section{PROCEDIMENTOS METODOLÓGICOS}

Foi realizado estudo da evolução, de 1999 a 2019, das contratações de crédito do Pronaf, em termos do montante de recursos e contratos firmados, bem como do total de crédito rural destinado à agricultura brasileira. Usou-se o arquivo de dados disponível no Banco Central do Brasil (BCB, 2020a), com os valores monetários sendo deflacionados pelo Índice Geral de Preços Disponibilidade Interna (IGP-DI) para 2019, de acordo com a tabela disponível na página eletrônica IPEADATA do Instituto de Pesquisa Econômica Aplicada (IPEA, 2020).

\footnotetext{
${ }^{5}$ É importante levar em conta que na safra 2013/14 a renda bruta anual dos agricultores familiares passou a ser contabilizada sem os chamados "rebates", descontos considerados no faturamento de determinadas atividades produtivas (AQUINO \& SCHNEIDER, 2015). Ou seja, na prática, o aumento da renda bruta, de 2012/2013 para 2013/14, para enquadramento no Pronaf não foi efetivamente de $\mathrm{R} \$ 160$ mil ( $\mathrm{R} \$ 220$ mil) para $\mathrm{R} \$ 360$ mil.

$6 \mathrm{Um}$ documento que apresenta as atuais linhas do Pronaf pode ser encontrado em https://www.bnb.gov.br/ documents/165130/165145/tabela_grupos_Pronaf-Jul_18.pdf/5b0c0718-698e-7d73-f311-fe0b06f3fa5b.
} 
As mudanças institucionais ocorridas no período de análise foram consultadas junto a publicações do Ministério do Desenvolvimento Agrário (MDA), extinto em 2016, e do Ministério da Agricultura, Pecuária e Abastecimento (MAPA).

Comparou-se a distribuição do volume financeiro e número de contratos do Pronaf (custeio e investimento juntos) com, respectivamente, a renda bruta e número dos agricultores familiares das grandes regiões geográficas brasileiras. Estas últimas duas informações foram obtidas nas edições dos censos agropecuários de 2006 e 2017, a cargo do Instituto Brasileiro de Geografia e Estatística (IBGE). Para delimitação do universo de agricultores familiares nos censos usou-se o critério estabelecido em 2017, para este ano e, retroativamente, também para 2006, conforme adaptação feita pelo próprio IBGE e disponível em seu site.

Neste caso, deixaram-se de lado as informações de crédito rural de 1999 e 2000 e, para o subperíodo 2001-2011 (cinco anos antes e cinco depois de 2006), consideraram-se as participações das regiões no número e na renda bruta de agricultores familiares constantes e iguais às do Censo 2006. Para o subperíodo 2012 a 2019 (cinco anos antes e dois depois de 2017), tomaram-se as participações do Censo 2017. Tal suposição foi necessária devido a inexistência de dados censitários para todos os anos e não se consideraram os dois subperíodos com igual número de anos, evidentemente, pela recente execução do Censo 2017. Outra observação é que, no mais das vezes, as participações das regiões nos dois censos não foram muito diferentes, exceto no caso do Nordeste, em que sua participação na renda bruta da agricultura familiar caiu, significativamente, de 2006 para 2017.

Ao se comparar, para cada região, a participação porcentual dos valores do Pronaf com a da renda bruta da agricultura familiar (que será chamada de conformidade de renda) ou a relação entre a participação porcentual do número de contratos do Pronaf com a do número de agricultores familiares (conformidade de agricultores), assume-se que a distribuição neutra se daria quando essas relações tivessem o valor unitário. Este valor estando acima de 1,0 para determinada região, revelaria que a mesma está sendo relativamente beneficiada na distribuição dos recursos e contratos do Pronaf, e o inverso se daria quando esse valor fosse menor que 1,0.

Para o que aqui se pretende, seria ideal que se tivessem informações da distribuição do Pronaf por agricultores familiares classificados de acordo com faixas de renda. Como isto não é possível, 
usou-se a renda média dos estabelecimentos agropecuários de cada região como uma aproximação da importância relativa de agricultores mais ou menos pobres.

Adota-se a simplificação de que o Nordeste pode ser tomado como representação geográfica dos agricultores familiares mais pobres, aos moldes do terceiro grupo de agricultores considerado por Guanzirolli et al. (2009), citado anteriormente. Enquanto isto, o Sul seria caracterizado pelos agricultores familiares mais capitalizados, do primeiro grupo de Guanzirolli et al. (2009), com as outras três regiões apresentando situações intermediárias. Na seção seguinte apresentam-se dados que dão consistência, em termos médios, a esta simplificação, não se esquecendo que no interior de cada região há também diferenciações sociais entre os agricultores familiares.

Ao se comparar a distribuição dos recursos e contratos do Pronaf com, respectivamente, a renda bruta e o número de agricultores familiares das regiões geográficas brasileiras, será possível avaliar se o critério social, de beneficiar relativamente os mais pobres, foi um importante guia na execução do Pronaf, entre 1999 e 2019.

\section{RESULTADOS E DISCUSSÃO}

A Tabela 1 mostra que houve queda no número de estabelecimentos da agricultura familiar, entre 2006 e 2017, de 9,5\%, enquanto o de não familiares crescia $35 \%$ e o total de estabelecimentos agropecuários caía em 2\%. Em 2006, os familiares representavam 83,2\% do total de estabelecimentos agropecuários no Brasil, valor que caiu para 76,8\%, em 2017. Ao mesmo tempo, sua participação na área total dos estabelecimentos reduziu-se de 24,4\% para 23,0\% (IBGE, 2019).

Tabela 1 - Número e área média de estabelecimentos agropecuários da agricultura familiar nas regiões geográficas do Brasil, 2006 e 2017.

\begin{tabular}{lcccccccc}
\hline \multirow{2}{*}{ Região } & \multicolumn{2}{c}{ Estabelecimentos Familiares 2006 } & \multicolumn{2}{c}{ Estabelecimentos Familiares 2017 } & \multicolumn{2}{c}{ Variação 2006-17 } \\
\cline { 2 - 9 } & Número & $\%$ & Ár. Méd. & Número & $\%$ & Ár. Méd. & Número & Ar.Med. \\
\hline Norte & 410.913 & 9,5 & 41,7 & 480.575 & 12,3 & 41,1 & 17,0 & $-1,4$ \\
Nordeste & 2.150 .244 & 49,9 & 13,3 & 1.838 .846 & 47,2 & 14,1 & $-14,5$ & 6,0 \\
Sudeste & 692.307 & 16,1 & 18,8 & 688.945 & 17,7 & 19,9 & $-0,5$ & 5,9 \\
Sul & 839.307 & 19,5 & 15,7 & 665.767 & 17,1 & 17,3 & $-20,7$ & 10,2 \\
C.-Oeste & 212.410 & 4,9 & 44,7 & 223.275 & 5,7 & 44,7 & 5,1 & 0,0 \\
\hline Brasil & 4.305 .105 & 100,0 & 18,9 & 3.897 .408 & 100,0 & 20,8 & $-9,5$ & 10,1 \\
\hline
\end{tabular}

Fonte: IBGE (2009, 2019).

Entre as regiões, observa-se que as participações relativas do Norte, Centro-Oeste e Sudeste aumentaram no total de estabelecimentos familiares, com crescimento absoluto nas duas primeiras. 
Por sua vez, o Nordeste e o Sul perderam importãncia relativa no total de estabelecimentos familiares. Apenas em regiões de fronteira, com a área agrícola não consolidada e presença de grandes projetos de assentamentos de reforma agrária, houve expansão do número de agricultores familiares. Em 2017, ainda quase metade dos agricultores familiares brasileiros eram da Região Nordeste, bem acima das demais regiões.

A área média dos estabelecimentos familiares apresentou leve crescimento no Brasil e em todas as regiões, com exceção do Norte, entre 2006 e 2017. As áreas médias do Norte e do CentroOeste mostram-se superiores ao dobro da área média do Brasil e das outras três regiões.

Quanto à renda bruta ou valor da produção, a Tabela 2 mostra que o total da agricultura familiar apresentou leve queda, de 2006 a 2017, equivalente a 2\%, em grande parte pela redução de mais de $40 \%$ na renda do Nordeste. Nas outras regiões a renda da agricultura familiar apresentou aumento, muito expressivo no Centro-Oeste. Em termos médios, a renda dos agricultores familiares no Brasil cresceu $8,5 \%$, caiu $30,7 \%$ no Nordeste e $4,0 \%$ no Norte, enquanto se expandia em $8,2 \%$ no Sudeste e, mais expressivamente, no Sul, 33,3\% e Centro-Oeste, 45,0\%.

Por sua vez, na Região Sul a área média da agricultura familiar foi de 17,3 ha, em 2017, conforme Tabela 1, pouco acima do Nordeste. Muitos pequenos agricultores do Sul, atualmente, acessam tecnologias agropecuárias modernas, convivem com condições edafoclimáticas relativamente favoráveis e fornecem matéria-prima (frangos, suínos, leite, uvas, fumo etc.) para grandes empresas agroindustriais, abastecedoras do mercado nacional e internacional. No Sul, houve grande crescimento da renda média dos agricultores familiares, fazendo com que, em 2017 , ela equivalesse a quase 2,5 vezes a do Brasil todo. Neste mesmo ano, mais de $40 \%$ da renda da agricultura familiar do País foi auferida pelos agricultores desta região.

Tabela 2 - Valor da Produção total e médio dos estabelecimentos da agricultura familiar nas regiões geográficas do Brasil, 2006 e 2017.

\begin{tabular}{|c|c|c|c|c|c|c|c|c|}
\hline \multirow{2}{*}{ Região } & \multicolumn{3}{|c|}{ Valor Produção 2006 (R\$ mil) } & \multicolumn{3}{|c|}{ Valor Produção 2017 (R\$ mil) } & \multicolumn{2}{|c|}{ Variação VP } \\
\hline & Total & $\%$ & Médio & Total & $\%$ & Médio & Total & Médio \\
\hline Norte & 11.202 .172 & 9,2 & 27,3 & 12.613 .888 & 10,6 & 26,2 & 12,6 & $-4,0$ \\
\hline Nordeste & 30.107 .129 & 24,7 & 14,0 & 17.813.926 & 14,9 & 9,7 & $-40,8$ & $-30,7$ \\
\hline Sudeste & 26.876 .121 & 22,0 & 38,8 & 28.950 .231 & 24,2 & 42,0 & 7,7 & 8,2 \\
\hline Sul & 46.704 .000 & 38,3 & 55,6 & 49.310 .531 & 41,3 & 74,1 & 5,6 & 33,3 \\
\hline C.-Oeste & 7.068 .136 & 5,8 & 33,3 & 10.776 .712 & 9,0 & 48,3 & 52,5 & 45,0 \\
\hline Brasil & 121.957 .560 & 100,0 & 28,3 & 119.465 .286 & 100,0 & 30,7 & $-2,0$ & 8,5 \\
\hline
\end{tabular}

Fonte: IBGE (2009, 2019). Valores corrigidos pelo IGP-DI para 2019. 
No Sudeste, a renda média dos agricultores era aproximadamente $37 \%$ superior a do Brasil, em 2017, e a região se caracterizava como a segunda em importância da agricultura familiar, atrás do Nordeste, em número de agricultores, após o Sul, em valor da produção. Nas outras duas regiões, a importância da agricultura familiar era menos significativa, com agricultores do Centro-Oeste auferindo uma renda média bem mais alta que os do Norte.

Em suma, considerando-se os extremos, enquanto o Nordeste se destaca pelo grande número de agricultores familiares com baixo nível de renda média, o Sul apresenta alta participação na renda da agricultura familiar, fazendo com que seus agricultores tenham renda média bem superior aos de outras regiões.

\section{EXPansão do Pronaf no Brasil}

A Tabela 3 mostra que o volume financeiro do Pronaf cresceu expressivamente, entre 1999 a 2019, pouco acima do volume total de crédito rural no País. Na verdade, o crescimento ocorreu até 2014 , quando se atingiram $\mathrm{R} \$ 32.938,5$ milhões de crédito para os familiares e $\mathrm{R} \$ 186.438,3$ para médios e grandes. A partir deste pico, os recursos crediticios diminuíram.

Na média do período, o Pronaf representou $13 \%$ do volume de recursos de crédito rural para todos agricultores, inferior à participação da agricultura familiar na renda bruta da agricultura brasileira, estimada em 38\%, em 2006, e 23\%, em 2017 (IBGE, 2009, 2019).

Tabela 3 - Recursos do Pronaf e do total de Crédito Rural, Brasil, milhões R\$, 1999 a 2019.

\begin{tabular}{ccc|ccc}
\hline Ano & Pronaf & Total Crédito & Ano & Pronaf & Total Crédito \\
\hline 1999 & $7.398,2$ & $53.810,4$ & 2010 & $18.025,5$ & $141.298,3$ \\
2000 & $7.252,5$ & $58.021,8$ & 2011 & $19.314,2$ & $147.907,1$ \\
2001 & $6.841,8$ & $66.998,4$ & 2012 & $22.766,1$ & $170.663,7$ \\
2002 & $6.562,6$ & $72.797,4$ & 2013 & $27.593,3$ & $196.008,9$ \\
2003 & $8.576,9$ & $80.771,9$ & 2014 & $32.938,5$ & $219.376,8$ \\
2004 & $9.983,8$ & $97.769,7$ & 2015 & $27.143,5$ & $192.392,4$ \\
2005 & $12.981,7$ & $94.498,5$ & 2016 & $24.800,4$ & $179.954,6$ \\
2006 & $15.570,1$ & $97.946,4$ & 2017 & $24.982,0$ & $184.821,4$ \\
2007 & $14.551,1$ & $108.117,0$ & 2018 & $25.271,0$ & $191.476,7$ \\
2008 & $16.057,3$ & $121.932,9$ & 2019 & $24.914,9$ & $178.250,7$ \\
\cline { 4 - 5 } 2009 & $17.998,6$ & $134.189,3$ & Var. 2009-19 & 236,8 & 231,3 \\
\hline
\end{tabular}

Fonte: BCB (2020a). Valores corrigidos pelo IGP-DI para 2019. 
O Gráfico 1 permite verificar que, entre 1999 e 2002, enquanto os recursos do Pronaf caíam, revertendo o crescimento entre 1996 e 1999 (BACCARIN, 2011), os créditos para médios e grandes agricultores cresciam. Este crescimento continuou ocorrendo de 2003 a 2014, agora acompanhado por aumento, mais intenso, do Pronaf. A partir de 2014, o decrécimo do Pronaf foi mais forte.

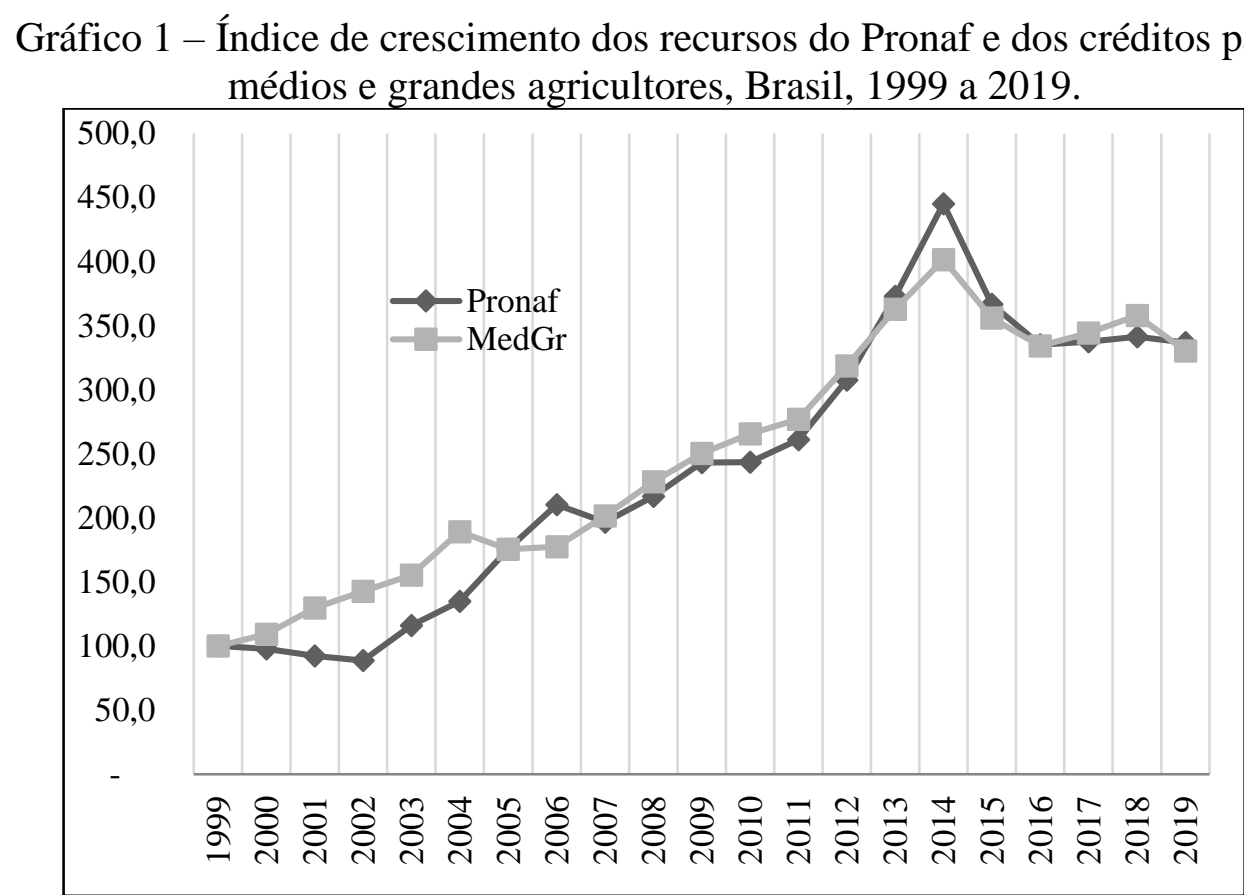

Fonte: BCB (2020a). Valores monetários corrigidos pelo IGP-DI para 2019.

No Gráfico 2 observa-se grande crescimento, de 2003 a 2006, do número de contratos do Pronaf, de 1.026.689 para 2.563.590, em termos absolutos. Relevando o fato de que um mesmo agricultor pode fazer mais de um contrato/ano, os contratos do Pronaf em 2006 corresponderam a $60 \%$ do número de agricultores familiares levantados, no mesmo ano, pelo Censo Agropecuário. 
Gráfico 2 - Índices de recursos financeiros, número e valor médio dos contratos do Pronaf, Brasil, 1999 a 2019.

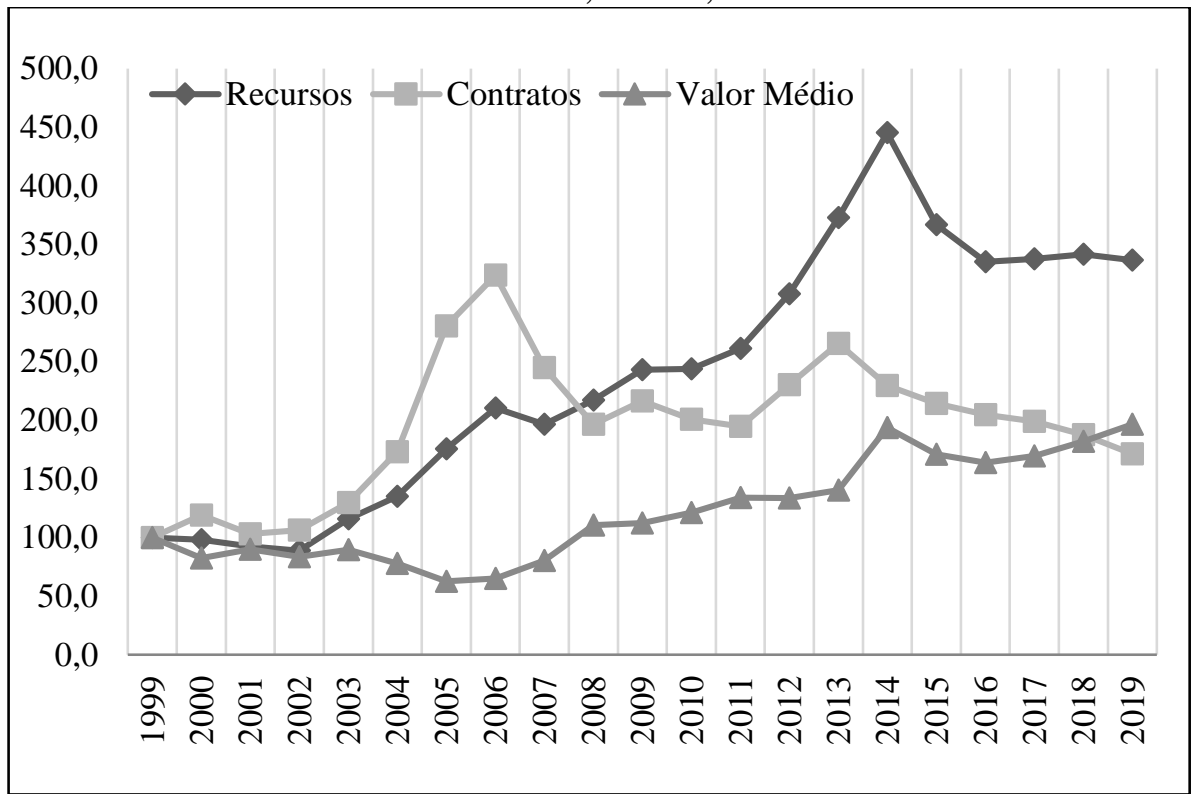

Fonte: BCB (2020a). Valores monetários corrigidos pelo IGP-DI para 2019.

Contudo, tal redistribuição teve curta duração, com o número de contratos reduzindo-se bruscamente, de 2006 a 2008, para 1.556.507. A partir daí, pode-se dizer que houve uma instável recuperação até 2013, quando o número de contratos foi pouco superior a 2,1 milhões, seguida de uma contínua queda. No final do período, 2019, foram assinados 1.356 .603 contratos do Pronaf, crescimento de $71 \%$ em relação aos 791.677 de 1999, contra elevação de $237 \%$ no seu volume financeiro. Consequentemente, o valor médio dos contratos apresentou crescimento quase contínuo, após 2006, mais que triplicando e alcançando R \$ 18,36 mil, em 2019.

Não se desconsiderando a diferença de dois anos nos períodos, a elevação do valor médio dos contratos do Pronaf foi bem maior que o crescimento de 8,5\% na renda média da agricultura familiar, de 2006 a 2017, conforme Tabela 2.

As alterações já citadas nos limites de enquadramento e dos créditos de investimento e custeio do Pronaf aparecerem como explicação evidente desta reconcentração do Programa, após 2006. Especulativamente, pode ter ocorrido reação dos bancos responsáveis pelo Programa, com destaque ao Banco do Brasil, afetados pelo aumento dos seus índices de risco de crédito com a ampliação do número de contratos, o que carece de comprovação empírica. 
Em termos sociais, mais especificamente no que se refere ao crescimento da participação daqueles agricultores familiares mais pobres, não se conseguiu sustentar a intenção, mais ambiciosa, observada entre 2003 e 2006. A partir de 2007, o valor médio dos contratos do Pronaf passou a crescer, o que pode ser tomado como um indicador de que agricultores familiares com maiores áreas ou mais capitalizados foram relativamente mais beneficiados.

\section{Participação das Regiões Geográficas no Pronaf}

Os gráficos 3, 4 e 5 mostram a distribuição do volume financeiro, número de contratos e valor médio dos contratos entre as regiões brasileiras.

Gráfico 3 - Índice de recursos financeiros do Pronaf, regiões geográficas do Brasil, 2001 a 2019.

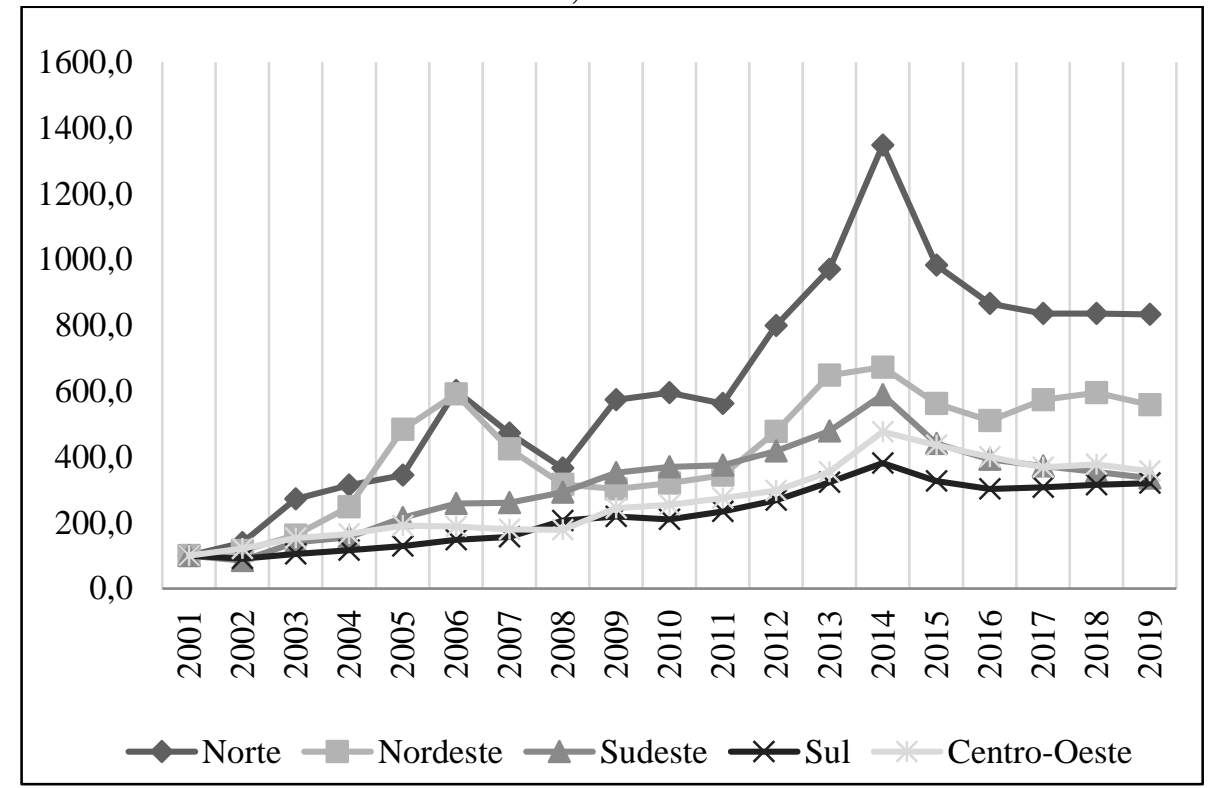

Fonte: BCB (2020a). Valores monetários corrigidos pelo IGP-DI para 2019.

No Sudeste, Sul e Centro-Oeste o crescimento, em todo o período, dos recursos do Pronaf foi superior a 200\%, no Nordeste a $400 \%$ e no Norte a $700 \%$ (BCB, 2020a). Este último valor pode ser explicado, em parte, pelo aumento da importância da agricultura familiar no Norte, verificado entre os censos de 2006 e 2017, além de sua base inicial ser reduzida. Percebe-se no Gráfico 3 que o Nordeste, inicialmente, apresentou desempenho parecido com o do Norte, depois houve queda 
nos recursos do Pronaf, seguida de recuperação, a partir de 2011, com esta região, em todo o período, se colocando como a segunda em termos de elevação dos recursos do Programa. O Sudeste e o Centro-Oeste apresentaram desempenho parecido, abaixo do Nordeste, e no Sul foi onde se verificou o menor crescimento dos recursos do Pronaf.

Em termos do número de contratos, Gráfico 4, o grande aumento inicial verificado no Nordeste não se sustentou, mesmo assim foi esta região que apresentou o maior crescimento neste quesito, seguida pela Região Norte, com esta apresentando queda expressiva no final do período. Em posição intermediária ficou o Sudeste e com desempenho mais desfavorável, o Centro-Oeste e o Sul. Em 2019, o número de contratos no Centro-Oeste era apenas 3\% superior ao de 2001 e no Sul, $21 \%$ inferior.

Gráfico 4 - Índice do número de contratos do Pronaf, regiões geográficas do Brasil, 2001 a 2019.

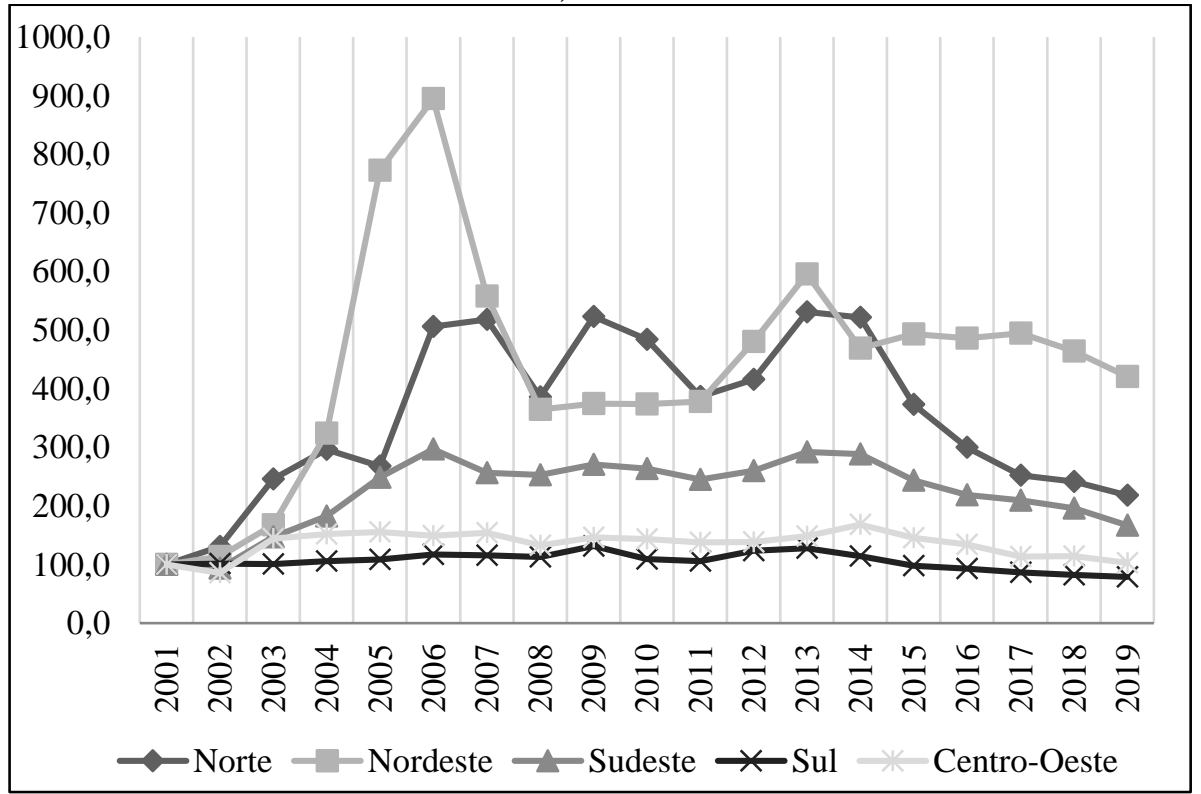

Fonte: BCB (2020a). 
Gráfico 5 - Índice do valor médio dos contratos do Pronaf, regiões geográficas do Brasil, 2001 a 2019.

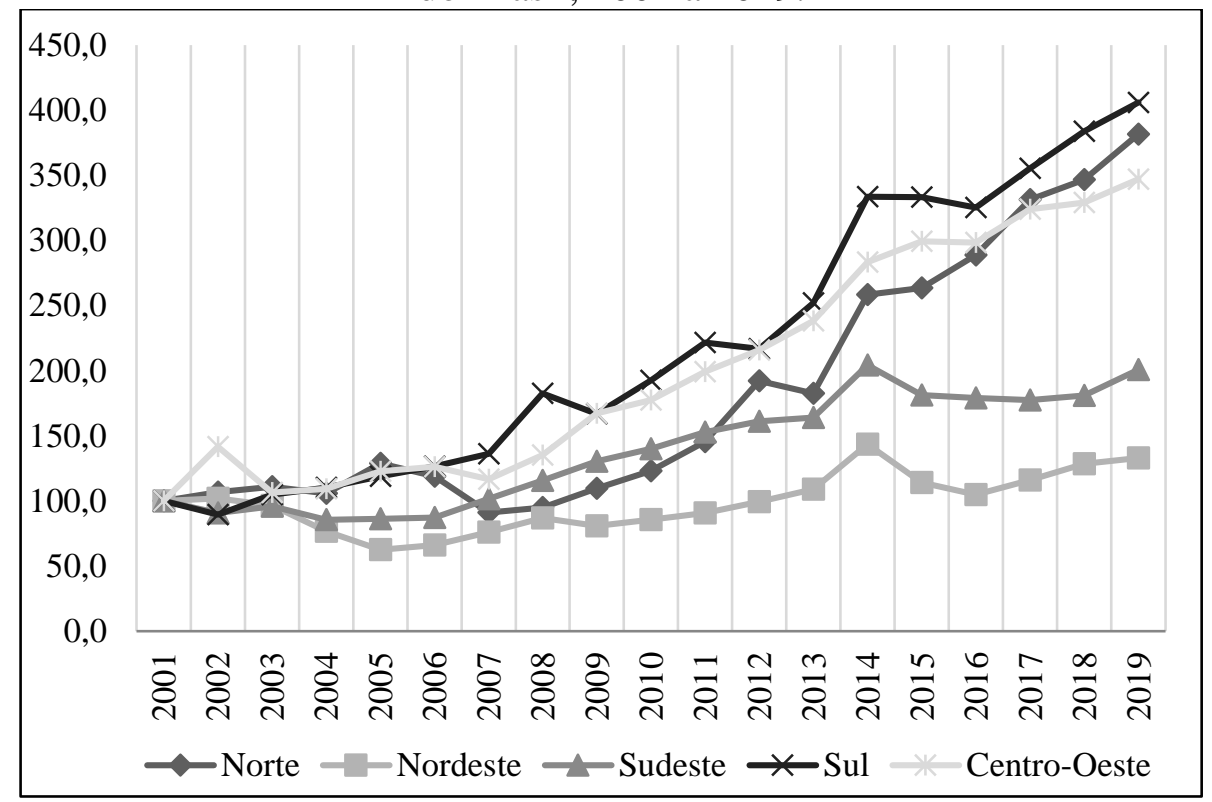

Fonte: BCB (2020a). Valores monetários corrigidos pelo IGP-DI para 2019.

Justamente no Sul foi onde se verificou o maior aumento relativo do valor médio dos contratos do Pronaf, conforme Gráfico 5. Até certo ponto, isto está relacionado com o aumento da renda bruta e redução do número de agricultores familiares observados entre os censos agropecuários de 2006 e 2017, mas não se descarta a hipótese de que houve aumento da concentração dos recursos e da taxa de exclusão de agricultores locais do Pronaf. No outro extremo, no Nordeste verificou-se o menor crecimento do valor médio dos contratos do Pronaf, de apenas $32 \%$, entre 2001 e 2019. Nesta região houve maior proximidade na evolução dos recursos financeiros e contratos do Pronaf.

$\mathrm{Na}$ Tabela 4, para que todos os triênios fossem constituídos, considerou-se o período 1999 a 2019 e podem ser destacados alguns resultados. A Região Norte aumentou muito sua participação nos recursos do Pronaf, embora ela continuasse relativamente baixo no triênio 2017-19. A Região Nordeste mais do que dobrou sua participação nos contratos do Pronaf, superando 50\% no último triênio, ao mesmo tempo que, até o triênio 2005/07, sua participação nos recursos financeiros cresceu significativamente, depois caiu, embora apresentasse no final uma participação levemente superior ao do triênio 1999/2001. 
Tabela 4 - Participação porcentual das regiões geográficas brasileira no valor e no número de contratos do Pronaf, triênios de 1999 a 2019.

\begin{tabular}{cccccccccccc}
\hline \multirow{2}{*}{ Ano } & \multicolumn{3}{c}{ Norte } & \multicolumn{2}{c}{ Nordeste } & \multicolumn{2}{c}{ Sudeste } & \multicolumn{2}{c}{ Sul } & \multicolumn{2}{c}{ Centro-Oeste } \\
\cline { 2 - 10 } & Valor & Contr. & Valor & Contr. & Valor & Contr. & Valor & Contr. & Valor & Contr. \\
\hline $1999 / 01$ & 3,5 & 3,3 & 12,9 & 22,6 & 17,6 & 11,6 & 59,8 & 58,8 & 6,1 & 3,7 \\
$2002 / 04$ & 5,7 & 4,0 & 13,8 & 30,6 & 17,7 & 13,1 & 54,1 & 47,9 & 8,6 & 4,4 \\
$2005 / 07$ & 6,6 & 3,8 & 23,5 & 56,5 & 20,2 & 12,2 & 43,4 & 24,9 & 6,4 & 2,6 \\
$2008 / 10$ & 5,2 & 3,7 & 16,8 & 36,6 & 18,5 & 12,3 & 52,4 & 43,9 & 7,0 & 3,6 \\
$2011 / 13$ & 6,7 & 4,8 & 14,1 & 45,4 & 21,7 & 14,9 & 51,0 & 32,0 & 6,6 & 2,9 \\
$2014 / 16$ & 7,8 & 5,4 & 13,7 & 47,8 & 19,7 & 14,8 & 51,3 & 28,8 & 7,6 & 3,2 \\
$2017 / 19$ & 6,7 & 3,2 & 15,6 & 53,7 & 16,7 & 13,1 & 53,9 & 27,2 & 7,2 & 2,8 \\
\hline
\end{tabular}

Fonte: BCB (2020a). Valores monetários corrigidos pelo IGP-DI para 2019.

Praticamente o contrário ocorreu no Sul, uma queda para menos da metade na participação no número dos contratos e leve diminuição no volume financeiro do Programa, que havia sido mais forte até o triênio 2005/07. As participações do Sudeste e do Centro-Oeste não mostraram grandes variações, com o Programa se revelando mais expressivo na primeira.

\section{CONFORMidAde de Renda E DE Agricultores}

Levando em conta a variável conformidade de renda, definida no item 3, o Gráfico 6 revela que em 2006 ocorreu a distribuição mais equânime dos recursos do Pronaf, com esta variável se aproximando da unidade para todas as regiões. Antes, Sul e Centro-Oeste tinham uma situação privilegiada, Norte e Nordeste muito desfavorável e Sudeste desfavorável. A partir de 2007, a distribuição ficou mais desigual em relação a 2006, embora não voltasse à situação de 2001-2002. De 2012 a 2019, o Sul recebeu recursos financeiros do Pronaf superiores à sua contribuição para a renda bruta da agricultura familiar, Norte, Sudeste e Centro-Oeste, abaixo, e Nordeste, muito próximos. A situação mais favorável do Nordeste, em 2012-19 em relação a 2007-11 tem que ser relativizada, pois não decorreu do aumento do volume de crédito, mas da queda da renda bruta de sua agricultura familiar, entre os censos de 2006 e 2017. 
Gráfico 6 - Relação entre participação porcentual nos recursos do Pronaf e na renda bruta da agricultura familiar, regiões geográficas, Brasil, 1999 a 2019.

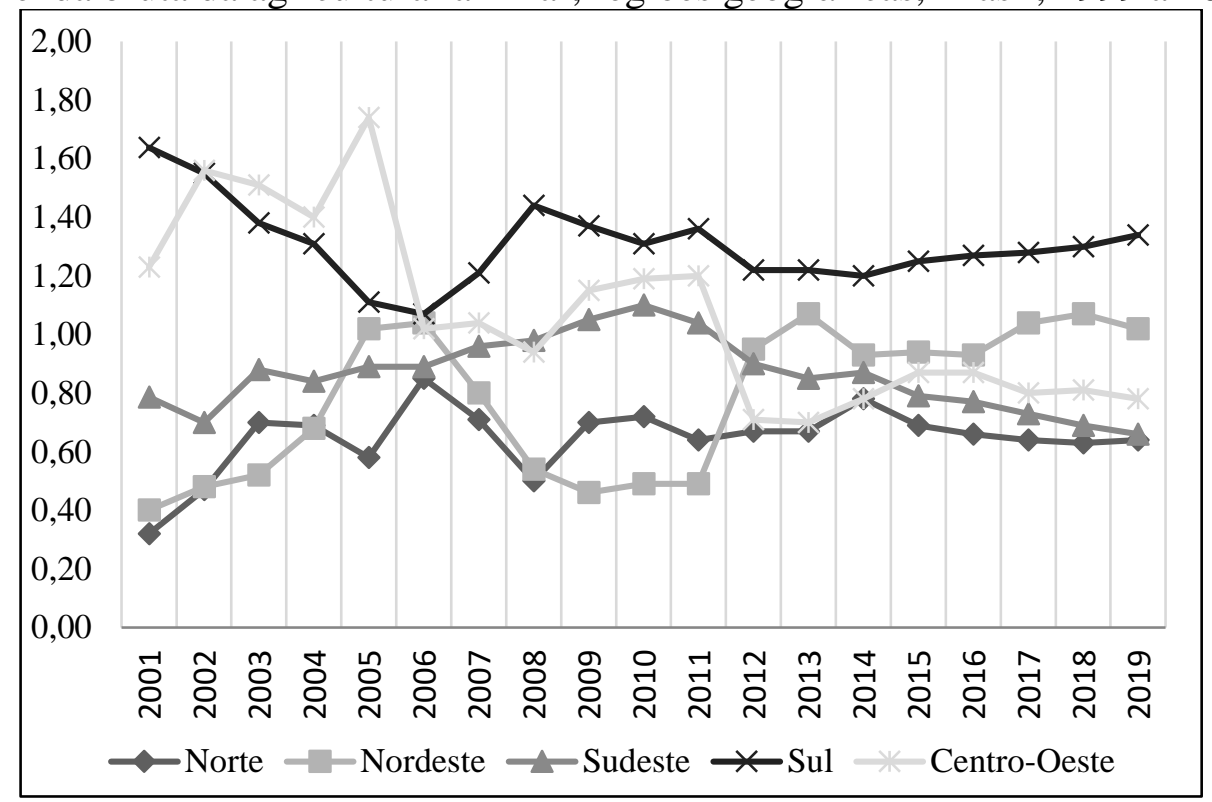

Fonte: BCB (2020a), IBGE (2009, 2019). Valores monetários corrigidos pelo IGP-DI para 2019.

Na média de todo o período, 2001 a 2019, o Sul foi contemplado com recursos monetários do Pronaf $31 \%$ superiores à sua participação na renda bruta e o Centro-Oeste, $7 \%$ superiores. No Norte, eles foram 35\% inferiores, 22\% inferiores no Nordeste e 14\% inferiores no Sudeste. Duas explicações podem ser levantadas para a situação mais favorável do Sul: a organização de seus agricultores em associações e cooperativas, que permitiu que desde a criação do Programa eles mostrassem grande capacidade de mobilização e pressão sobre as instituições públicas; a renda média mais alta de seus agricultores, conferindo-lhes melhor tratamento por parte dos bancos operadores do Pronaf. Adicionalmente, comente-se que, de acordo com Baccarin et al. (2016), a distribuição desigual dos recursos do Pronaf entre as regiões esteve associada a operações de custeio. No caso dos contratos de investimento, ao longo do período 1999 a 2013, os autores mostram que a participação das regiões nos recursos do Pronaf tendeu a se aproximar de suas respectivas participações na renda bruta da agricultura familiar.

Em termos de distribuição do número de contratos, observa-se no Gráfico 7 que a Região Sul sempre foi relativamente bem mais beneficiada, embora tal fato tenha se atenuado no período todo, mais fortemente em 2005 e 2006. Na média de todo o período, 2001 a 2019, a participação nos contratos do Pronaf superou em $84 \%$ a participação no número de agricultores da Região Sul. 
Por sua vez, na Região Nordeste, desconsiderando-se os três anos iniciais, a média de conformidade de agricultores foi igual a um. Na média de todo período, a participação nos contratos do Pronaf foi inferior a $60 \%$ à participação dos agricultores familiares do Norte, $16 \%$ inferior no Sudeste e $35 \%$ inferior no Centro-Oeste.

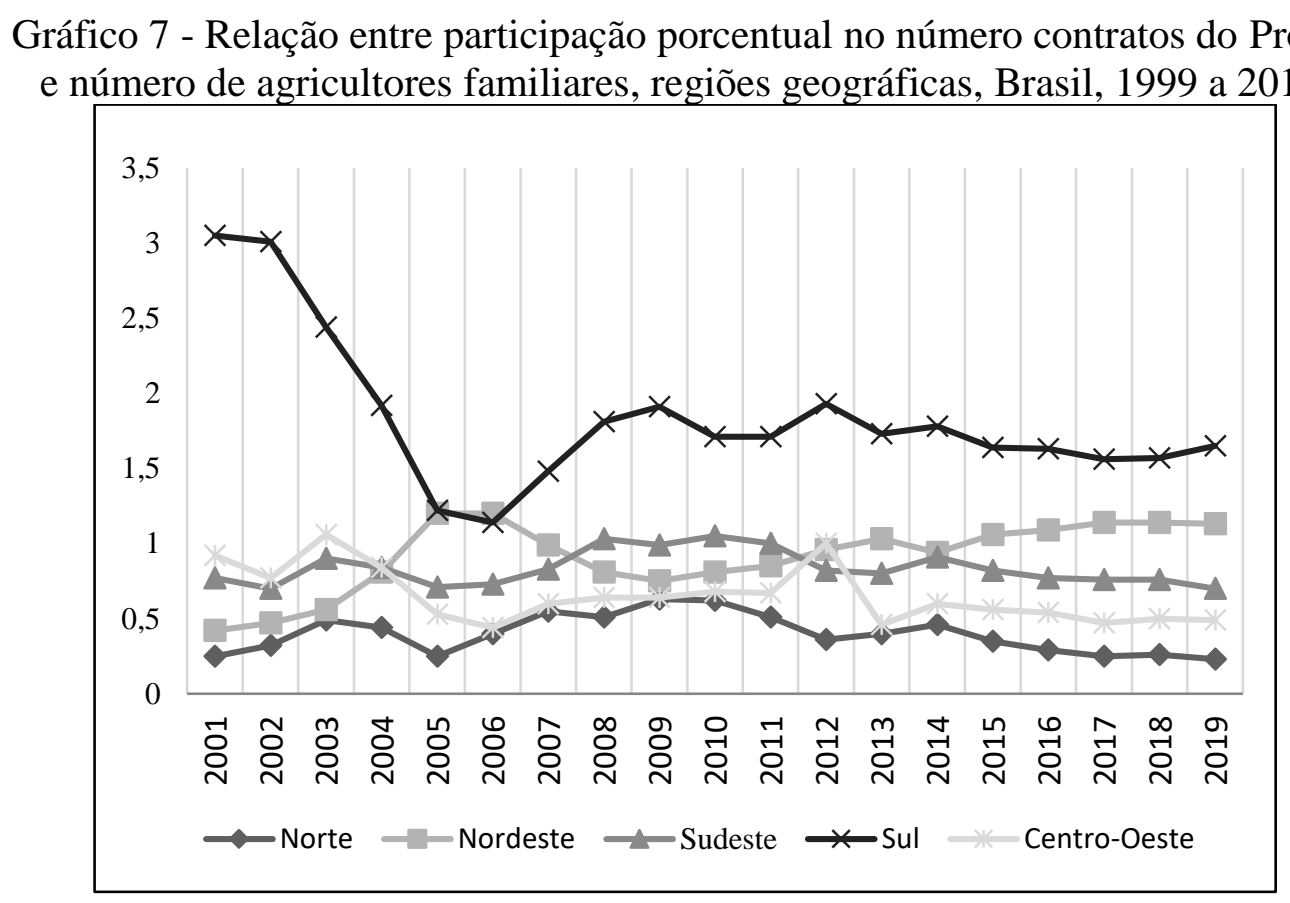

Fonte: BCB (2020a), IBGE (2009, 2019).

\section{CONSIDERAÇÕES FINAIS}

Pode-se considerar que, entre 1999 a 2019, houve tendência de aumento dos recursos do Pronaf no Brasil e em suas regiões geográficas, muito parecido com o acontecido com os créditos para médios e grandes agricultores. Tal crescimento não foi constante e, rigorosamente, pode-se estabelecer que, entre 1999 a 2002, houve variação dos recursos do Pronaf, com exceção de 2007, de 2003 a 2014, e apresentaram tendência de redução, de 2015 a 2019. Contudo, os agricultores familiares continuaram recebendo valor relativamente menor de volume de crédito rural oficial em comparação à sua participação na renda bruta da agricultura brasileira.

Em relação às mudanças de participação relativa das regiões nos recursos e número de contratos do Pronaf, como mais significativas apontam-se que, entre 1999-2001 e 2017-19, o volume de recursos quase dobrou na Região Norte, o número de agricultores familiares 
contemplados mais do que dobrou no Nordeste e caiu para menos da metade no Sul. Em 2019, próximo a 54\% dos recursos do Pronaf se direcionavam para a Região Sul e também próximo a $54 \%$ dos contratos foram firmados com agricultores do Nordeste. O Sudeste aparecia com importância intermediária na percepção de recursos e contratos, enquanto o Norte e Centro-Oeste mantinha posição bem menos significativa no Programa.

Entre 2001 e 2019, as variáveis conformidade de renda (participação nos recursos do Pronaf sobre participação na renda bruta da agricultura familiar) e de agricultores (participação nos contratos do Pronaf sobre participação no número de agricultores familiares) tiveram seus valores em queda na Região Sul, embora se mantivessem bem acima da unidade, no final do período. Por sua vez, no Nordeste houve aumento nestas variáveis, embora no caso da renda isto se deveu à diminuição da renda bruta local, entre 2006 e 2017, e não ao aumento dos recursos do Programa.

Entre 2003 e 2006, as intenções distributivistas dos recursos do Pronaf em favor de agricultores mais pobres mostrou forte efetividade, merecendo destaque o aumento de participação, inclusive no volume financeiro, dos agricultores familiares do Nordeste, que têm renda média bem mais baixa que os das demais regiões. Contribuíram para isto mudanças institucionais, como a criação de novas modalidades do Pronaf, entre elas o Pronaf Semiárido. A variável conformidade de renda aproximou-se da unidade em todas as regiões.

Contudo, a partir de 2007, outras modificações institucionais, como a criação do Pronaf Mais Alimentos, elevação dos limites financeiros para enquadramento no Programa e dos créditos de custeio e investimento, tiveram efeito em direção contrária. Com isto a distribuição do Pronaf entre as regiões ficou mais desigual, embora não tão concentrada como no início do período, em 2001.

Outro ponto que merece ser destacado é que o valor médio dos contratos do Pronaf cresceu em todas as regiões, muito fortemente no Norte, Sul e Centro-Oeste e de forma pouco significativa no Nordeste. No Sul, o crescimento expressivo da renda bruta média de seus agricultores familiares junto com a elevação dos recursos do Pronaf explica, em parte, esta situação, mas também deve ser levado em conta a redução de mais de $20 \%$ no número de agricultores da região contemplados com o Programa, de 2001 a 2019. Por sua vez, no Nordeste a evolução dos recursos e do número de contratos foram mais parecidas, sugerindo que nesta região o processo de concentração dos recursos do Pronaf entre seus agricultores foi menor do que o ocorrido no Sul. 
Três pontos são sugeridos para futuros estudos, procurando melhorar a percepção sobre as causas das alterações na distribuição dos recursos do Pronaf entre as regiões e agricultores brasileiros. O primeiro é considerar as diferenças existentes no interior das regiões, entre seus estados, municípios e tipos de agricultores familiares. O segundo é estudar a atuação dos bancos públicos federais do Programa, inclusive o BASA e o BNB, em aspectos administrativofinanceiros, como o número de contratos, taxas de inadimplência e garantias oferecidas, bem como seu posicionamento institucional em relação ao Pronaf. O terceiro é analisar as reivindicações e mobilizações de entidades sociais representativas dos agricultores familiares, mais ricos e mais pobres, e sua eventual aderência às modificações institucionais realizadas no Programa, entre 2003 e 2019.

\section{REFERÊNCIAS}

ABRAMOVAY, R. \& VEIGA, J. E. Novas Instituições para o Desenvolvimento Rural: o caso do Programa Nacional de Fortalecimento da Agricultura Familiar (Pronaf). Brasília: Convênio FIPE/IPEA 07/97. (Textos para Discussão, 641).

ABRAMOVAY, R. \& PIKETTY, M. G. Política de crédito do Programa Nacional de Fortalecimento da Agricultura Familiar (Pronaf): resultados e limites da experiência brasileira nos anos 90. Cadernos de Ciência \& Tecnologia, Brasília, v. 22, n. 1, p. 55-66, jan./abr. 2005.

AQUINO, J. R. de \& SCHNEIDER, S. O Pronaf e o desenvolvimento rural brasileiro: avanços, contradições e desafios para o futuro. In: GRISA, C. \& SCHNEIDER, S. (Orgs.). Políticas públicas de desenvolvimento rural no Brasil. Porto Alegre: Editora da UFRGS. 2015. P. 53 81 .

AZEVEDO, F. F. \& PESSÔA, V. L. S. O Programa Nacional de Fortalecimento da Agricultura Familiar no Brasil: uma análise sobre a distribuição regional e setorial dos recursos. Revista Sociedade \& Natureza, Uberlândia, ano 23, n.3, 483-496, set/dez. 2011.

BACCARIN, J. G. Sistema de produção agropecuário brasileiro: características e evolução recente. 2 ${ }^{\mathrm{a}}$. Edição. São Paulo: Cultura Acadêmica, UNESP, 2011.

BACCARIN, J. G. et al. Conformidade na distribuição dos créditos do Pronaf: análise em relação ao número e à renda bruta de estabelecimentos da agricultura familiar nas regiões geográficas brasileiras. Geografia, Rio Claro, v. 41, n. 3, p. 549-566, set./dez. 2016.

BCB (Banco Central do Brasil). Anuário do Crédito Rural do Brasil 2012. Brasília: BCB. 2013.

BCB (Banco Central do Brasil). Manual do Crédito Rural do Brasil. Atualização MCR 679, de 15 de abril de 2020. Brasília: BCB, 2020. 
BCB (Banco Central do Brasil). Matriz de Dados do Crédito Rural - Contratações. 2020. Disponível em: https://www.bcb.gov.br/estabilidadefinanceira/micrrural. Acesso em: 15 abr. 2020.

BIANCHINI, V. Vinte anos do PRONAF, 1995-2015: avanços e desafios. Brasília: SAF/MDA, 2015.

BRASIL. Decreto 1.946, 28 de junho de 1996. Cria o Programa Nacional de Fortalecimento da Agricultura - Pronaf, e dá outras providencias. Diário Oficial [da] República Federativa do Brasil, Brasília, 28 de junho de 1996. Disponível em: <www.planalto. gov.br/ccivil _03/decreto/D1946.>. Acesso em 12 março 2015.

BRASIL. Ministério do Desenvolvimento Agrário. Secretaria da Agricultura Familiar.

Programas: Pronaf. Disponível em: <www.mda.gov.br/portal/saf/programas/Pronaf>. Acesso em: 24 fev. 2015.

BRASIL. Ministério da Agricultura Pecuária e Abastecimento. Grupos e Linhas de Crédito PRONAF - Quadro Resumo (Plano Safra 2019/2020). Brasília: Banco do Nordeste, 2020. Disponível em: https://www.bnb.gov.br/documents/165130/228956/tabela_grupos_Pronaf_19122 018.pdf/9e353e24-d3e9-39ef-2698-14f212171a61. Acesso em: 12 abr. 2020.

BUAINAIN, A. M. \& SOUZA FILHO, H. M. A política agrícola no Brasil: evolução e principais instrumentos. In: Batalha, M. O. (Org.). Gestão Agroindustrial. São Paulo: Atlas. Vol. 2. 5. ed. 2009.

CONTI, B. M. de.; ROITMAN, F. B. Pronaf: uma análise da evolução das fontes de recursos utilizadas no programa. Revista do BNDES, v. 35, pag. 131-168, junho de 2011.

DELGADO, N. G. Política econômica, ajuste externo e agricultura. In: LEITE, S. (Org.). Políticas públicas no Brasil. Porto Alegre: Editora da Universidade, 2001. Pag. 15-52.

GRISA, C.; WESZ JUNIOR, V. POLÍTICAS PÚBLICAS PARA A AGRICULTURA FAMILIA R: entre avanços e desafios. OPPA, Rio de Janeiro, v. 33, n. 1, p. 1-4, maio 2010.

GUANZIROLLI, C. E. Pronaf dez anos depois: resultados e perspectivas para o desenvolvimento rural. Revista de Economia e Sociologia Rural, Rio de Janeiro, v. 45, n. 02, pag. 301-328, abr./jun. 2007.

GUANZIROLLI, C. E.; BUAINAIN, A. M.; DI SABATTO, A. Agricultura familiar - uma análise comparativa 1996-2006. In: Congresso Brasileiro de Economia, Administração e Sociologia Rural, 48, 2009. Campo Grande. Anais... Brasília: SOBER, 2009.

IBGE (Instituto Brasileiro de Geografia e Estatística). Censo Agropecuário da Agricultura Familiar 2006. Rio de Janeiro: IBGE, 2009. 426 p.

IBGE (Instituto Brasileiro de Geografia e Estatística). Censo Agropecuário do Brasil 2017. Rio de Janeiro: IBGE, 2019.

IPEA. (Instituto de Pesquisa Econômica Aplicada). IPEADATA - Indicadores

Macroeconômicos. Disponível em: 〈www.ipeadata.gov.br〉. Acesso em 12 abril de 2020. 
MATTEI, L. Políticas de apoio ao desenvolvimento da agricultura familiar no Brasil: o caso recente do Pronaf. Revista Econômica do Nordeste, Fortaleza, v. 38, n. 1, p. 143-158, jan-mar. 2007.

MATTEI, L. Evolução do crédito do Pronaf para as categorias de agricultores familiares e A/C entre 2000 e 2010. Revista Econômica do Nordeste, Fortaleza, v. 45, n. 3, p. 58-69, jul-set., 2014.

NUNES, S. P. O crédito rural do PRONAF e os recentes instrumentos de política agrícola para a agricultura familiar: Conjuntura Agrícola, n. 156, p. 1-10, fev. 2007.

REBELLO, A. Seca de 2012 a 2017 no semiárido foi a mais longa na história do Brasil.

Disponível: https://noticias.uol.com.br/meio-ambiente/ultimas-noticias/redacao/2018/03/03/ secade-2012-a-2017-no-semiarido-foi-a-mais-longa-da-historia.htm?cmpid=copiaecola. 03/ 03/2018. Acesso em 26 de abril de 2020.

SACHS, I. Brasil Rural: da redescoberta à reinvenção. Estudos Avançados, v. 15, n. 43, p. 7582, 2001.

SCHNEIDER, S.; MATTEI, L.; CAZELLA, A. A. Histórico, caracterização e dinâmica recente do PRONAF - Programa Nacional de Fortalecimento da Agricultura Familiar: In: SCHNEIDER, S.; SILVA, M. K.; MARQUES, P. E. M. (Orgs.). Políticas públicas e participação social no Brasil rural. Porto alegre, 2004. p. 21-50.

SAYAD, J. Crédito rural no Brasil. São Paulo: FIPE/Pioneira, 1984. 125 p.

SILVA, S. P.; FILHO, E. A. Impactos Econômicos do Pronaf em Territórios Rurais: Um Estudo para o Médio Jequitinhonha - MG. Revista Econômica do Nordeste, Fortaleza, v. 40, n. 3, p. 481-498, jul-set., 2009.

SOUZA, P. M. et al. Análise da Evolução do Valor dos Financiamentos do Pronaf-Crédito (19992010): número, valor médio e localização geográfica dos contratos. Revista de Economia e Sociologia Rural, v. 51, n. 2, p. 237-254, abr./jun. 2013.

SOUZA, P. M. et al. Análise da distribuição dos financiamentos rurais entre os estabelecimentos agropecuários brasileiros. Revista de Economia e Sociologia Rural, v. 53, n. 2, p. 251-270, abr./jun. 2015. 